\title{
A NOTE ON SQUIRREL DAMAGE TO CONIFERS
}

\author{
By R. E. Balch, \\ Dominion Entomological Laboratory \\ Fredericton, N.B.
}

$\mathrm{O}$

$F$ THE perennial inquiries received at the laboratory, one of the most frequent relates to the discovery of large numbers of fallen shoots, about two inches long, on the ground beneath fir and spruce trees. Since the explanation of this is often received with considerable scepticism even by foresters, it seems worth while to record some facts regard. ing it.

It is very common in the Maritime Provinces to find such shoots practically covering the ground, particularly beneath balsam fir trees approach. ing maturity. This is most noticeable on the snow during the late winter, but freshly dropped shoots may be found from late summer to spring. The shoots will sometimes be gathered into a small pile. Many will be found to have borne male flower buds at the bases of the needles and in most cases these have been removed, together with a few of the needles on the underside. The shoot buds are generally intact.

This damage is caused by the red squirrel. It is surprising how seldom it is caught in the act. The writer observed a squirrel nipping off the shoots of a spruce on one occasion in Idaho during the winter. The habit has been reported in Europe. ${ }^{(1)}$

Another common type of injury consists of the cutting of leaders and sometimes laterals from the tops of small fir and spruce. Some of the large buds are often also removed. Many crooks and double leaders result, but spruce and fir generally correct these rapidly so that the form of the mature tree is not noticeably affected. Similar injury to pine, larch and white spruce has been reported by Hatt ${ }^{(2)}$ and others, and attributed to squirrels. It is sometimes serious in plantations.

The red squirrel supplements its winter diet of hoarded material with buds of various trees. In the Maritimes the balsam and fir flower buds are favoured and it obtains these by nipping off the shoots in large numbers at the base of the last year's growth. The large buds on the leaders and year-old laterals of young trees are also favoured and many leaders are bitten off to secure them. The injury under our forest conditions is, however, not very serious.

This kind of feeding apparently takes place mostly in late winter and spring, when other food becomes scarce. Unusual amounts may be evidence of an abundance of male flowers and an approaching seed year.

This injury should not be confused with the breaking off of partially grown shoots in early summer which frequently occurs during windstorms.

(1) Busgen, Munch and Thomson. Structure and Life of Forest Trees, London, 1929, p. 31. (2) Hatt, R. T. Roosevelt Wild Life Annals, Vol. 2: No. 1 N.Y. State Coll. of For. 1929. 